\title{
Crashaw and Abjection: Reading the Unthinkable in his Devotional Verse
}

There looms, within abjection, one of those violent, dark revolts of being, directed against a threat that seems to emanate from an exorbitant outside or inside, ejected beyond the scope of the possible, the tolerable, the thinkable. (Julia Kristeva, Opening of Powers of Horror)

Julia Kristeva begins her Powers of Horror by probing the belly of the beast. She is writing about abjection but her opening remarks would not sound out of place in a critical study of the seventeenth-century English poet Richard Crashaw. Indeed it is surprising how uncannily her words mirror the horrified reaction of many readers to his devotional verse on the Passion and Crucifixion, and especially to that little poem which imagines the unthinkable, "Blessed be the paps which Thou hast sucked."

Kristeva develops her theory of abjection out of Freud's speculation that the 'uncanny' is a primitive and instinctive reaction of dread and horror to what is unknown but strangely familiar, and which ultimately proves to be death, the hidden presence lurking in wait for us all throughout life. ${ }^{1}$ Kristeva argues that abjection is a psychic defense against a "massive" and life threatening attack of uncanniness in which the subject is assailed by a premonitory fear of what death carries like a carrion - the "loathsome," the "Not me," a "weight of meaninglessness ... on the edge of non-existence and hallucination ... that, if I acknowledge it, annihilates me" (2). As the stirring verses that end his poem "The Flaming Heart” illustrate, Crashaw did not fear but rather prayed fervently for this annihilation of self that beckons from the void of death. "Leave nothing of my SELF in me" (l. 106). He paid homage to St. Teresa of Avila's mystical victory over the powers of horror which put faith itself in extremis during the Reformation period. "Let me so read thy life, that I / unto all life of mine may dy” (ll. 107-08). ${ }^{2}$

Kristeva emphasizes the link between abjection and death by describing abjection as a manifestation of "the horror within," resulting from "the collapse of the border between [what is] inside and outside," what is under and beyond the control of the body (53). Abject articles that draw attention to the porous boundary between the 'me' and the 'not me', the 
subject and the objects taken into and expelled by the body, take three major forms in Kristeva's thinking.

The first is loathing for food that brings to mind detritus such as "skin on the surface of milk," the mucus of rotting vegetables or the pong of decaying flesh meat. The nausea and vomiting that this food can provoke is both an expression of abjection and an attempt to cleanse the body of its pollution. For as Kristeva says, “' 'I' expel it. But since the food is not an 'other' for 'me,' ... I expel myself, I spit myself out, I abject myself within the same motion through which 'I' claim to establish myself' (2-3).

The second expression of the abject is found in the horror arising from the spectacle of death, physical violence and disease. The still warm corpse transgresses the borderline between life and death, the animated subject and the inert object that has let go of its bodily functions. The wounded body weeps and oozes blood, plasma and sweat, and when infected, fills with pus and the sickly sweet smell of putrefaction. Kristeva comments that, "These bodily fluids, this defilement, this shit are what life withstands ...with difficulty, on the part of death” (3).

Finally Kristeva speculates that the dependent child's pre-oedipal fantasy of the allpowerful or so-called 'phallic' mother who begins life, as death will end it, can generate the most archaic, unruly and outlandish expressions of abjection. For at stake is the clumsy effort of the child to separate itself from the mother and attachment to her breast and become a self-sufficient subject; to achieve motor control over its body and so outgrow objectification as an animal who does nothing but cry, feed and shit; and to neutralize what Kristeva calls "the horrors of maternal bowels" (53) that spewed the newborn out and threaten to suck him back in again. Kristeva suggests that the devotee of the maternal abject sustains a dual fantasy of dissolution and wholeness, fragmentation and unity, disconnection and merger, attraction and repulsion "for the desirable and terrifying, nourishing and murderous, fascinating and abject inside of the maternal body” (Kristeva, 54). ${ }^{3}$

In the Anniversary poems that he wrote around the time of Crashaw's own birth circa 1613, John Donne elegized a fifteen year old virgin as an elixir of purity. Her premature death became the occasion for an apotropaic rite to ward off abjection and the horrors of the sexually mature, blood-stained and breeding female body that is an infectious carrier of original sin. "She tooke the weaker Sex, she that could drive / The poysonous tincture, and 
the stayne of Eve, Out of her thoughts, and deeds; and purifie / All" ("The First Anniversarie,” ll. 179-82). ${ }^{4}$ Menstruating, pregnant or lactating women, whose bodies discharge abject objects such as blood, the miscarried foetus, urine and faeces, tears, colostrum, and breast milk, can inspire what Kristeva calls “violent, dark revolts of being," particularly in the traditional male poet (1). Donne reacts with a shudder of distaste and mortal terror to females as the first cause of abjection in "The First Anniversarie" and laments that "There is no health ... We are borne ruinous: poore mothers crie, / That children come not right, nor orderly, / Except they headlong come, and fall upon / An ominous precipitation” (ll. 91, 95-98, p.274). The mother's gift of life delivers the child into the waiting hands of sin, corruption and death.

While Donne sees "no health" in the abject female body, Crashaw, in dramatic contrast, celebrates its vitality and regenerative power. ${ }^{5}$ He is not disturbed but fascinated by female physiology; and he makes either the abject sites of the female or the feminized body of Christ -- mouth, eyes, bosom, lap, womb, and wounds -- and its emissions -- milk, blood, tears, saliva, and even faeces -- "a well of water springing up into everlasting life” in his religious poetry (John 4: 14). ${ }^{6}$ The "soft bowels" of Christ the Redeemer discharge mercy on the Day of Judgment in “Dies Irae” (st. XII, Williams, 191). Mary Magdalene’s tears float upward in "The Weeper" (st. 4, Williams, 124) to the milky way and the waters above the firmament where they thicken into cream and evoke the loathing in critics that Kristeva reserves for abject food like milk with a skin. The Virgin Mother produces hot and cold running milk for the Christ Child from breasts that have the bizarre dual efficiency of a thermos and a water cooler in the "Hymn in the Holy Nativity" (ll. 61-64, Williams, 82). The Holy Innocents die while being nursed, in a flood of dissolution that blends the refined blood of their "Mothers Milk," the blood of the butchered maternal breast and the pure blood of the children's martyred bodies (“Upon the Infant Martyrs,” ll. 1-2, Williams, 10). The "milky fonts that bath [their] thirst” (“To the Infant Martyrs,” l. 3, Williams, 10) invite abject comparison with the blood spurting from severed veins and female body parts, and the milky froth bubbling from the mouth of the dying. The Magdalene “lickes” Christ's feet clean with saliva that is produced by floods of tears (" She began to wash his feet with teares and wipe them with the haires of her head,” l. 1, Williams, 13). These tears of contrition for carnal sin, in turn, stain his "faire" feet and the immaculate genitalia they euphemistically represent. ${ }^{7}$ However the flame-colored hair of the Magdalene wipes and burnishes the stain, thus highlighting the refining fire of the Passion. ${ }^{8}$ 
Mary Magdalene replicates this rite of abjection, pollution and purification in Crashaw's verse on the Passion of Christ. The "wounds of our crucified Lord” (pp. 24-25) are weeping and bloody mouths that become the blood-shot, smarting and tearing eyes of inconsolable grief. She is present at his Crucifixion to demonstrate that Christ's sorrow has no limits, and does so by profuse weeping and feverish kissing of his nailed feet. She presses her lips passionately against the open wounds of his feet, as though giving mouth-to-mouth resuscitation. Or through a veil of tears, perhaps it is more akin to tongue kissing; for the abject thrives on transgression of taboos and prohibitions (Kristeva, 15). In a divine epigram “On our crucified Lord Naked, and bloody” (Williams, 24), Crashaw visualizes what the Magdalene cannot see in self-abasement before the minor wounds. Here Christ fulfils the promise he made to his Father in infancy, during his first sacrifice at the Circumcision. "These purple buds of blooming death may bee, /Erst the full stature of a fatall tree" ("Our Lord in his Circumcision to his Father," ll. 15-16, Williams, 9-10). Now Christ's body hangs elevated above Mary Magdalene, naked, exposed and isolated on the Cross, clothed only in a seamless and rich crimson cloak of blood. Kristeva points out that "one of the insights of Christianity ... is to have gathered in a single move perversion and beauty as the lining and the cloth of one and the same economy" (125). This macabre garment is produced from the costly and majestic “purple wardrobe” (1.4) opened by the major wound in his side, but invisible to Magdalene in the divine epigram "On the wounds of our crucified Lord” where she kneels close up and kisses his feet. Abjection not only takes the part for the whole but loses sight of the whole in its fixation with and fetishization of the part. $^{9}$

Crashaw is the "Poet and Saint" of abjection. ${ }^{10}$ This is why critics with very different theoretical outlooks invariably fall back on the same words to describe his devotional art. The poet and/or his poetry have repeatedly been called the following: horrifying, shocking, scandalous, shameful, embarrassing, perverse, grotesque, repulsive, revolting, sick, disgusting, peculiar, eccentric, neurotic, effeminate, febrile, over-excited, erotic, pornographic, queer, lurid, weird, strange, primitive, and extreme. ${ }^{11}$ How can this be when Crashaw himself is so often characterized as inoffensive, innocent, unworldly, sweettempered, and child-like? I submit that what is being articulated here is a strong gut reaction to the somatized spectacle of abjection that Crashaw stages in his verse. Abjection forces both the spectator and reader to consider what is beyond the pale, or, as David Reid puts it, 
what is "beyond most people's emotional range” (157). Again and again there is the involuntary attraction to and recoil from the unthinkable.

Anthony Low presciently remarked in 1978 that "Crashaw puts human feelings to work in the service of devotion. He is a writer who by his daring can embarrass, offend, or provoke uneasy laughter" (Love's Architecture, 157). However while Low deems him the poet of embarrassment, I perceive the gag and the catch in the throat that are symptomatic of abjection. As a devotional poet Crashaw revered female saints and holy women who practised abjection. Kristeva argues that Christian mysticism makes abjection of self "the ultimate proof of humility before God;" and furthermore, that "the mystic's familiarity with abjection is a fount of infinite jouissance” $(5,127)$. We will need to consider how fully Kristeva's jouissance with its connotations of sexual bliss can account for Crashaw's eroticized spirituality. However, the ecstatic swell of emotion and upsurge of imagery that distinguish poems such as “The Weeper," “A Hymn to Sainte Teresa," “The Flaming Heart," and "Ode on a Prayer-book" do certainly suggest the pleasurable arousal of jouissance. As we have seen already, abjection leads to rapture in Crashaw's solemn Crucifixion and Passion poems. This is because, as Kristeva observes, abjection demands the death of the ego and, in return, promises resurrection. "It is an alchemy that transforms [the] death drive into a start of life, of new significance" (15).

Judaism's dietary laws, custom of purification for new mothers, and practice of male circumcision show how religion subdues the horror of abjection through rituals of cleansing that are invoked as prophylactics against pollution. Kristeva argues that abjection begins to take new forms when a prescriptive religion faces collapse (17). Christ's circumcision as an infant and presentation in the Temple enact his obedience to the Mosaic laws regulating abjection. However his adult ministry reflects his impassioned belief that pollution is not caused by what a man eats or excretes, and as a consequence, neither superficial observance of ritual hygiene nor outward purity of form can make him clean.

Listen, and understand: What goes into the mouth does not make anyone unclean; it is what comes out of the mouth that makes someone unclean. ... Can't you see that whatever goes into the mouth passes through the stomach and is discharged into the sewer? But whatever comes out of the mouth comes from the heart, and it is this that makes someone unclean (Matt 15; 10-18). 
Christ showed the fallacy inherent in the primitive distinction between clean and unclean. He turned religious observance inside out by insisting that a man will be judged on the 'inside,' in his heart and its good or “evil intentions," not on what he does 'outside' for show (Matt 15:19). In effect, he challenged his followers to confront abjection's powers of horror by recognizing that there is no clear-cut difference between 'me,' the 'not-me' and the demonized other; and that there is no safe dividing line between the clean and the unclean, the pharisaic self, the unruly body and the perverse spirit. The good news that he conveyed through his preaching and his body language was both wonderful and terrible. 'Do not be afraid.' 'Face your fears.' 'I have prevailed over abjection.' He drove home his point by sacralizing abject body objects and parts. He healed a deaf and dumb man by putting his fingers into the man's ears and touching his tongue with spit. He put his saliva on the eyes of a blind man and so cured him. He cured another blind man at the Pool of Siloam with a paste of dirt and spit. He drank water from the jar of an unclean Samaritan woman. $^{12}$ He ate with unwashed hands. He wrote with his finger in the dirt and pardoned the woman who had been caught in adultery. He cried over Jerusalem. He washed the unclean feet of the apostles and symbolically offered them his body and blood to consume at the Last Supper. He sweated blood and tears of anguish in the Garden of Gethsemane. He shed his blood on the Cross. After his Resurrection, he invited doubting Thomas to put his hand into the raw wound in his side.

Throughout his ministry, Christ deliberately sought close physical contact with abject persons. He presents himself to the vagrant holy man John for baptism and cleansing immersion in the River Jordan. He cures unclean lepers and a man suffering from a repulsive skin-disease by his touch. He repeatedly exorcises those who are afflicted by evil spirits and their destructive energies in the gospels. He heals an epileptic who foams at the mouth. He forgives the sins of a paralytic and then, reading the evil minds of the scribes, gives an outward sign of his power over the inner man by commanding him to take up his bed and walk home. He invites unclean tax collectors and sinners to eat food with him at table. He heals a woman who has suffered from a haemorrhage of blood for twelve years and who has been condemned to life as an untouchable. He lets a woman of ill repute touch his feet with her mouth and clean them with her abject tears and loosened hair. Christ recognized and embraced those who were regarded as odious outsiders or treated as abject others to be hounded out of respectable society. 
While an undergraduate scholar at Pembroke College, Cambridge, between 1631-1635, Crashaw was required to compose Latin and Greek epigrams on the Scriptural readings for each Sunday. ${ }^{13}$ As his modern editor George Walton Williams has noted, these early epigrams in the Epigrammata Sacrorum Liber were the petri dish in which Crashaw worked on subjects and themes that would assume great importance in his mature poetry (258). ${ }^{14}$ Even as a young apprentice poet, Crashaw treated abjection with panache. John's abject sense of unworthiness to baptize the spotless Jesus in Matthew 3:13-15 allows the poet to play with the paradox that the waters in which Christ immersed himself are washed clean by his holy limbs (“On the water of the Lord’s baptism,” Williams, 298). Matthew 9:11 was an occasion to explore the Pharisees' obsession with their fine, upstanding, outer impeccability and distaste at Jesus' degrading association with disreputable publicans and diseased sinners who are, ironically, far less wicked than the Pharisees ("Why eateth your Master with publicans?”, “Why eateth your Master with sinners?”, Williams, 314). In Matthew 4:24 Crashaw found an occasion to commemorate Jesus' counter-offensive against the death drive and the dark energies of the mind with his healing of the mentally ill who were in the grip of "those diseases night and Hell call their own” (“And they brought unto him all sick people, and those which were possessed with devils,” Williams, 316). In an original and unexpected take on the scene in Matthew 9: 20-22 where the woman diseased by a twelve year haemorrhage of blood is cured by touching the hem of Christ's garment from behind, Crashaw explored a feature of abjection that he would take up later in his Crucifixion poems. When brought in contact with Christ, blood no longer pollutes but is sanctified. Even fully clothed, Jesus shows a naked, gut compassion for others. "When [Christ] so reveals himself at the finger of a faithful person, is he not then - even when clothed - then also unadorned love?” (Williams, 326). In a later English epigram, as we have already seen, Christ will hang naked on the Cross, adorned only in the blood of sacrificial love. Here the function of his raiment is not to cover the stained and shameful body but to act as a shining semiconductor of salvation. ${ }^{15}$

Matthew 15:21-28 furnished inspiration for three significant Latin epigrams Crashaw wrote on Jesus' encounter with the woman of Canaan. ${ }^{16}$ This perplexing encounter starkly dramatizes the power of abjection. It should be noted that the passage on the woman of Canaan immediately follows Matthew's account of how Jesus teaches his disciples a new meaning of the clean and unclean. "For from the heart come evil intentions: murder, adultery, fornication, theft, perjury, slander. These are the things that make a person unclean. 
But eating with unwashed hands does not make anyone unclean” (Matthew 15: 19-20). Matthew, in other words, wishes us to "behold" the woman of Canaan as a direct illustration of Christ's radical lecture on defilement (15: 21-28). She appears suddenly when Jesus takes his ministry to coastal tribes in Canaan and Phoenicia who were marginalized and demonized by the Jews. Her daughter is possessed by a devil but the louder she cries for Jesus to have pity, the more silent and unresponsive he appears to become. His disciples plead in embarrassment, "Give her what she wants, because she keeps shouting after us," a request which indirectly suggests the power of persistent prayer. Yet Jesus' reluctant answer seems to underline her outsider status. "I was sent only to the lost sheep of the House of Israel.” With nothing to lose, the woman now abjects herself utterly before Jesus. In the final and most severe test of her need of him and selfless love for her daughter, he callously replies, "It is not fair to take the children's food and throw it to little dogs." Undeterred, the woman of Canaan is prepared to let go of her little remaining pride and accept Jesus' abject definition as an animal. "Ah yes, Lord; but even little dogs eat the scraps that fall from their masters' table.” His answer reflects admiration, amazement and whole-hearted responsiveness. "Woman, you have great faith. Let your desire be granted.” Like Mary Magdalene, the woman of Canaan is not demeaned but ennobled by her abjection at the feet of Christ. The disintegration of her ego is likened to the scraps that fall on the floor from the table. Though broken, these scraps are blessed. They have not been "cast to dogges or swine,” as Crashaw warned in a later hymn on the Blessed Sacrament, but internalized by a worthy recipient. The miracle that ensues, in which the woman of Canaan's “daughter was made whole from that very hour," foreshadows the Eucharistic mystery which transmits “whole CHRIST in every crumme” (“Lauda Sion Salvatorem,” Williams, 183),

Over the course of his three sacred epigrams on this scriptural passage, Crashaw developed the core idea that Christ does his sacred work through abjection. In "Christ rather obstinate toward the woman of Canaan,” he suggests that the harder the woman begs, supplicates and abases herself, the more obdurately Christ seems to withhold his help. However the epigram "On the woman of Canaan," suggests a subtle shift in abject subject position as the woman wears Christ down with her entreaties. "See, he is yielding. Now at this moment he will give in. ... Now, if your hand does not fail you, now he will fall.” In fact, she cannot see any outer, visible change in attitude. But she may sense what is happening inside as Christ himself "feels the strength in you and he loves it." Kristeva suggests that where abjection is given a biblical status, the “'subject' and 'object' push each other away, confront each other, 
collapse, and start again - inseparable, contaminated, condemned, at the boundary of what is assimilable, thinkable: abject” (18). Christ eventually is condemned to admit defeat at the woman's hands. Crashaw proclaims the good news of her heroic victory in his third and final epigram on the subject, joyfully putting Christ's words of astonishment into his own mouth, "A woman, and of such strong faith? now I believe that faith is/more than grammatically of the feminine gender" ("The woman of Canaan," Williams, 334). Matthew's scriptural passage on the woman of Canaan and Crashaw's youthful poetic reaction to it also bear out Kristeva's view that "the subject of abjection is eminently productive of culture. Its symptom is the rejection and reconstruction of languages” (45). This remark seems particularly apropos to a poet who would translate his sacred epigrams from Latin and Greek into English form, who was fluent as well in Hebrew, Spanish, French, and Italian, ${ }^{17}$ and who, as David Punter observes, "writes in, and between, languages ... lives between domains and between cultures” (53). Kristeva also suggests that the poet of abjection fills his mouth with words as a substitute for the 'good breast' of the mother (41).

I shall proceed to consider this last idea in relation to a sacred epigram in English which is a supreme test of faith for Crashaw’s readers. "Blessed be the paps which Thou hast sucked" arouses the visceral dislike, the acute discomfiture, and "the dirty pleasure" of abjection and marshals these feelings to try and "excite adoration."18 The question is -- does the epigram succeed or fail horribly?

Suppose he had been Tabled at thy Teates,

Thy hunger feels not what he eates:

Hee'l have his Teat e're long (a bloody one)

The Mother then must suck the Son. (Williams, 14)

The Latin epigram from which this startling poem derives is about as exciting as Gerber baby food. "And what if Jesus should indeed drink from your breast? ... And soon He will lay bare his breast - alas, not milky! - from her son then the mother will drink" ("Blessed is the womb and the paps," Williams, 324). As both Robert Young and Anthony Low appreciate, Crashaw knew what he was doing when he eroticized and sensationalized the imagery in the English version (Young, Richard Crashaw and the Spanish Golden Age, 25, Low, Love's Architecture, 146). The word which he substitutes for the wholesome verb 'drink' (Latin bibit) and which makes the message of the poem so controversial is 'suck.' It is a verb rooted in the flesh and slick with the body fluids of abjection. "Suck" provides the 
punch and the gasp of breath in the final line of the poem. Crashaw deliberately engineered these affects by the alliterative link between the verb and its grammatical object 'the Son' of God. The English epigram is not a tame translation, but is it fair to call it a perversion of the original?

The Latin epigrammatic source is based on a passage in Luke 11: 27 where a woman interrupts Jesus' preaching by crying aloud "Blessed is the womb that bare thee, and the paps which thou hast sucked.” The English epigram takes the words from the mouth of the woman and makes them the title of the poem. ${ }^{19}$ It becomes apparent here that the substitution of the English word 'suck' for the Latin word meaning 'drink' is a purer translation of scripture even if it seems a corruption of the Latin epigram Crashaw wrote as an undergraduate. It is remarkable that he should once again poeticize a gospel passage that immediately follows Christ's teaching on abjection. This time Jesus gives a parable on the return of an unclean spirit with "seven other spirits more wicked than itself" to take up habitation in the soul. Freud suggests that the return of such animistic beliefs is a mark of the uncanny and can reflect "repressed infantile complexes (or) womb phantasies" ("The 'Uncanny',” 370-72). The unidentified woman, who cries out to Jesus like the woman of Canaan, is responding euphorically to his personal magnetism as a preacher and exorcist. Her response is a womb phantasy in which she lifts her voice in praise and envy of the maternal body privileged to bear and suckle him. However, he discourages her from perceiving his mother as a figure of singular sanctity. This is because extreme idealization feeds off the very demonization that he has just dispelled and can thus lead to a return of even more intense feelings of abject unworthiness and pollution. When this happens, Christ warns in his parable, "that (unclean) person ends up worse off than before". He thus reminds the woman, "More blessed still are those who hear the word of God and keep it" (Luke 11: 26, 28). He exhorts her to imbibe his holy words rather than extol the good breast (Kristeva, 45). He invites all who heed his words to consider themselves more privileged than his mother.

When Crashaw formulated "Blessed be the paps," he interpreted Christ's words more strictly than Luke as an invitation to become his mother in spirit. He seems to have been influenced by the passage succeeding the parable of the unclean spirit in the synoptic gospel of Matthew 12: 50 where Jesus snubs his mother, gestures to his disciples, and proclaims that "anyone who does the will of my Father in heaven is my brother and sister and 
mother.” As devout "chaplaine of the virgine myld” at Peterhouse (Williams, 653), Crashaw would have found it difficult to conceive of Mary, the mother of the God, as a figure who simply fades away into the background of Jesus' ministry. Yet the perception of the mother as a person of magical bounty, whose body parts - breast and womb - succor to the child's every need, represents a fiction of primary narcissism. ${ }^{20}$ Psychic development requires the child to imagine the mother whole and entire and separate from the self. Adrian Stokes argues that, "without a concomitant development of the good breast into the good wholeobject we cannot be at home in an adult world: we cannot discern sufficiently between ourselves and objects nor feel ... respect and brotherhood ... with the stranger” (8). Christ's words in Luke encourage detachment from the womb and paps that are maternal partobjects. They provoke the transference and transformation of personal love for the mother into impersonal love for the stranger. They challenge his followers to make the relationship to the mother whole and complete by expanding it to include other people.

For Kristeva, New Testament narratives such as the ones I have discussed illustrate Christ's emphasis on interior as opposed to exterior abjection. "It is permanent and come from within. Threatening, it is not cut off but is reabsorbed into speech. Unacceptable, it endures through the subjection to God of a speaking being who is innerly divided and, precisely through speech, does not cease purging himself of it” (113). Indeed she specifically cites the woman of Canaan's encounter with Jesus as an example of how Christian faith requires an interiorization of abjection (115). ${ }^{21}$ In effect, Kristeva is saying that wo/men are life prisoners of abjection, constantly engaged in the vain attempt to exclude the unclean other and project it outside through psychic splitting, linguistic disavowal, religious prohibitions, cultural taboos, and social ostracism. Christ demonstrated otherwise by his words and deeds. He healed those who were prisoners of inner division and phobia. He sought out the despised and rejected. He identified with outsiders and invited strangers, foreigners and pariahs to become his "brother and sister and mother."

Crashaw challenges his poetic readers to "suppose" that they were wet nurses to Jesus. While the critical scholars of this epigram have by and large been men, the poem is formally addressed to the archetypal woman in Luke 11 who sees the mother of Christ as supremely blessed, and who hungers for Mary's intimate nursing bond with him. It is not the idea of mothering Jesus or being the primary caretaker, but breastfeeding him, that makes it almost unthinkable for male readers to identify with this devout woman. Some take the 'prefer not 
to' approach or evade this identification by moving with all possible speed to the second or third line of the poem where Jesus no longer makes a spectacle of himself as a suckling but becomes a more active subject increasingly in control of himself and the faithful. Others see the way fixed gender definitions are subverted in the opening and final lines of the poem, but resist the feminization that is first required from them as male readers to focus on the transfiguration that Jesus makes from breastfed Son to nourishing maternal God. ${ }^{22}$

However the epigram actively discourages this avoidance by opening with the imperative verb "Suppose." "Suppose" licenses the reader to move "beyond the scope of the possible, the tolerable, the thinkable” (Kristeva, 1), and allow the perverse and sacred, beautiful and profane, sublime and sordid power of abjection to work on the imagination. In lowering the psychic defenses against abjection, this poem seems to know no negation. "Suppose” says yes to the unthinkable. Yet if "suppose" is an open invitation, Crashaw immediately runs the imagination smack into the stone wall of the verb "Tabled." While the word is a clear reference to the communion altar table, William Empson suggests that "Tabled" may also allude to the Torah, the Judaic law and the stone tablets on which Moses inscribed God's ten commandments (221). "Tabled” is thus a reminder not only of bounty but of duty. It modifies the meaning of the opening verb and calls to mind what we are 'supposed to do.'

None of this explains away the oddity in Crashaw's clever play on words and syntax. Thomas Healy gets stuck on how impossible the first line is by asserting "the Child could not be 'tabled' at [Mary's] breasts, since the word indicates sacramental food available only from Christ,” while recognizing that 'mother' is an inclusive term not reserved for Mary alone in this poem (55). Eugene Cunnar offers a theological explanation that illustrates Christ's teaching that "for God everything is possible" (Matt 19:26). He cites a follower of Bernard of Clairvaux who theorized that there are "two altars, one in the breast of Mary, the other in the body of Christ; Christ sacrificed His flesh, Mary her soul” (“Crashaw's 'Sancta Maria Dolorum'," New Perspectives on the Life and Art of Richard Crashaw, 104). "Tabled" creates an impossible object of veneration out of contradiction - the hard and stony altar made by a mother's soft breasts - and like abjection, is built on a foundation of antithesis. "Tabled” also evokes the benign image in Psalm 23: 4-5 of a speaker who "fear(s) no evil: for you are at my side"; and who believes "you prepare a table for me in the sight of my enemies.” The paps of the woman now repay this divine hospitality but the monstrous image begins to intrude of Christ not only taking his first - as opposed to last -- supper at 
her breasts but feeding carnivorously off them with disturbing gusto. ${ }^{23}$ In "O Gloriosa Domina," Crashaw will go on to suggest that Christ is so happy with this arrangement that he takes up permanent room and board at Mary’s breast.

The whole world's host would be thy guest

And board himself at thy rich BREST.

O boundless Hospitality!

The FEAST of all things feeds on thee. (ll.7-10, Williams, 195)

“Tabled” cleverly suggests the intense love and hate that the mother inspires in the helpless infant, and the tendency to split and objectify her as the good and bad breast. Freudian psychoanalyst Melanie Klein points out that the good breast does not simply alleviate hunger but provides intense oral pleasure when the infant's "mouth is stimulated by sucking at his mother's breast. This gratification is an essential part of the child's sexuality, and is indeed its initial expression. Pleasure is experienced also when the warm stream of milk runs down the throat and fills the stomach” (290). In his own paraphrase of Psalm 23 which ranks among his earliest poetic works - Crashaw articulated the satiated pleasure and contentment which the infant finds in the good breast. "Pleasure sings my soule to rest, / Plenty weares me at her brest” (ll. 9-10, Williams, 5). However as Klein also observed, the infant's conflicted feelings towards the mother, and frustration when the breast is withheld, can lead to destructive and cannibalistic fantasies of "biting, chewing up and thus destroying their object” (293). Nursing Christ is not always the serene activity it appears in Renaissance sacred art but a potentially painful and even savage encounter, as the cracked nipples and sore or abscessed breasts of women who have actually persevered with breastfeeding, especially as first time mothers, can attest.

The surprise of the second line is sprung with the opening two words - "Thy hunger.” This makes an obvious devotional point: that mankind's spiritual need of Christ's salvation is infinitely greater than his brief infantile craving for his mother's milk. However "hunger" also suggests the sweet satisfaction or jouissance that women derive from breastfeeding. At the same time it nudges them to acknowledge the aspects of this pleasure that may give secret shame - the oral stimulation of the mammary as an erotogenic zone, the disgust for the infant who roots like an animal at the breast, and the aggressive impulse to hurt the child or to eliminate its dirt through obsessive cleanliness (Klein, 312). The final half of the line returns to contemplate the blunt fact of the Incarnation: that God is a man and must eat. The food he eats is both clean and unclean. He sucks milk which, according to Clement of 
Alexandria, has been converted from the refined blood of the mother, "forced up into the breasts," as if they function like a cappuccino machine. This milk contains the pure colostrum that provides antibodies against disease. Yet the bodies of nursing women do not only imitate Christ's sacrifice of his own spotless blood on the Cross; they also carry and genetically transmit the stain of original sin. "As the blood accumulates, the breasts begin to distend and the blood begins to turn into milk, like its change in an infected wound into pus” (Steinberg, 15, 18, 379). When Jesus is nursed by Christian devout souls, he is sucking poison from their wounds of original sin. Or to paraphrase Donne in "The First Anniversarie," he filters out "the poysonous tincture, and the Staine of Eve, / ... and purifie(s) / All, by a true religious Alchimy” (ll. 180-82, Shawcross ed., 277).

Yet the third and fourth line of the final couplet mirrors abjection's profane downturn of the mind from the pure to the perverse, from the image of benign nursing to blood-thirsty aspiration. "Hee'l have his Teat e're long (a bloody one) / The Mother then must suck the Son.” Crucified, Christ becomes an exhibition of what the mystery of the Incarnation and his Virgin Mother's parthenogenesis make him -- a freak of nature. Empson responds memorably, with vivid imagination, to the abjection in this Crucifixion tableau.

The sacrificial idea is aligned with incest, the infantile pleasures, and cannibalism; we contemplate the god with a sort of savage chuckle; he is made to flower, a monstrous hermaphrodite deity. ... Those African carvings, and the more lurid forms of Limerick, inhabit the same world (221). ${ }^{24}$

Empson's stimulating views capture the strangeness of this pierced and protuberant God who has the life sucked out of him on the Cross. Empson's reaction has elements of the jesting wonder that Lewis Carroll's Alice shows when she encounters a unicorn, that Christlike creature of medieval fable. In the Looking-Glass World where even commonplace sayings get reversed, she can't believe what she sees -- that this "fabulous monster" is alive and talking. While she and the unicorn see the truth of 'the other' staring them in the face and agree: “If you'll believe in me, I'll believe in you” (287), there has been considerable critical reluctance to 'see' or visualize the fabulous monstrosity of Crashaw's poetic scene. ${ }^{25}$ When readers have looked intently, they have often responded with an abject outpouring of disgust and revulsion (Sabine, Feminine Engendered Faith, 185-86). 
Crashaw's editor, George Walton Williams, dismisses Empson's description of the faithful "sucking a long bloody teat which is also a deep wound" (221) as pure invention (14). Kristeva suggests that such critical dogmatism can reflect the effort to "protect [oneself] from the shameful” disturbance of abjection (1). Empson looked this abjection straight in the face. He astutely saw that Crashaw put the word "long” in close proximity to "Teat" not only to pun on the fact that Longinus' spear caused the wound in Christ's side but to play on the abject sense that this bloody pap is both mammary and phallic. ${ }^{26}$ Empson's description of “a long bloody teat” insists that Christ's wound is at one and the same time phallic masculine and maternal feminine. Moreover it is a reminder that both the breast and the penis are "the primary objects of the infant's oral desires" and are the body parts that give rise to the early fantasy of the phallic mother who is all-providing and undemanding (Klein, 408-09). Crashaw’s epigram simultaneously recognizes the pull of the narcissistic fiction of the mother who is wholly at the disposal of the child and weans the reader off the naïve egotistic desire to "be loved always, everywhere, in every way, my whole body, my whole being - without any criticism, without the slightest effort on my part” (Chodorow, 79, 62).

Crashaw's epigram requires the reader to work at recreating the whole body in and through the person of Christ. Leo Steinberg has studied Renaissance portraits of the Virgin and Child that draw attention to the fact that the nursing infant Jesus and the crucified Christ inhabit the same fully human body, one that knows both sexual stirrings and hunger pangs. Indeed some painters went so far as to portray Christ as homo erectus at the beginning as well as at the end of his life, in Mary's lap, reclining against her swelling breast and later at the Crucifixion (Steinberg, 18, 76-80, 131-32). Crashaw was not only keenly interested in Renaissance religious art but an accomplished painter himself (Cunnar, "Opening the Religious Lyric,” 254-56, Low, Love’s Architecture, 117, Martin ed., 416). The Divine Epigrams in English open with "On the Blessed Virgins bashfulnesse," a poem that pictorializes the many holy pictures in which the Mother gazes in adoration at the Incarnate Child God in her lap. “'Twas once looke up, 'tis now looke downe to Heaven” (1.8, Williams, 9). In the divine epigram I focus on in this essay, Crashaw proceeds to look up from the Virgin's lap to her pap. Once again he had a visual model of Incarnational theology and worship in mind when he constructed his poem. ${ }^{27}$ It was not an impossible stretch for him as an artist to imagine the pap as both maternal and phallic because it is a fusion of the nursing anatomy in Renaissance devotional paintings where "the Christ Child designates or exposes at the same time his penis and the maternal breast” for the express 
edification of the spectator (Steinberg, 132). For the devout women whom he first addressed in his poem, Jesus' phallic manhood was not the most palpable sign of his full participation in their female bodily humanity. It was the mouth that sucked and kissed their teat, the hand that fondled and blessed their breast. Indeed Crashaw pushed "Christianity's greatest taboo" to the ultimate limit by exciting both erotic and religious thought in the first and last lines of his poem so that, like it or not, we must contemplate both the sexed body of Christ and that of the woman who is his natural or adopted "Mother." As Alison Shell wryly observes: "students both of sexuality and of religion at this period have been less broad-minded than Crashaw himself: perhaps because, until very recently, interest in one has commonly accompanied a distaste for talking about the other” (100).

"Blessed be the Paps" is a remarkable poem, terse but packed with meaning, cleverly constructed so that each line brings the reader face to face with the power, the glory and the horror of abjection. Its concrete and tactile vocabulary - “Tabled,” “Teates,” “eates,” "suck" - gives material form to the words of Psalm 34: "Taste and see that the Lord is good” (8); and calls attention to the fact that spirituality and sensuality exist on a continuum. Crashaw sanctifies both the early sensual hunger to be full of the mother and the later sexual desire to be filled by another and transforms them through his poetic alchemy into at-onement with Christ. The female mystic, Julian of Norwich, had a comparable vision of Jesus dying of thirst upon the Cross and in a flash of sudden insight, saw him as a Mother longing to "have us all together whole in him" (Pelphrey, 142). We arrive at a similar insight in Crashaw's epigram only by wrestling line by line with the dissolving boundaries between the self and the other, the subject and the object, the 'Mother' and the 'Son.' In effect we are forced to relive the past abjection of childhood. For the same reason, the poem discourages the mind-body split that functions to hold at bay the horror of abjection and to cope with its central anxiety -- that "the border between inside and outside" can collapse (Kristeva, 53). This splitting has led to the fractious and counter-productive debate of Leo Steinberg and Richard Rambuss with Caroline Walker Bynum over whether the wound in Christ's side should be seen as mammary, phallic or even vaginal. Ironically all three critics honor the body's place in religious devotion as a polymorphous site and understand that mystical vision exceeds gender and sexual limits; but they still implicitly privilege one symbolic form that the body of Christ takes over others. In the case of the feminist scholar Bynum, it is the maternal, lactating and generative Christ. In the case of the queer theorist Rambuss, it is the homoerotic Christ feminized, penetrated and violated at the Crucifixion. And in the 
case of Leo Steinberg, it is the "deathbound and sexed" body of Christ glimpsed in the genital display of the cradle and cross. (Rambuss, 13-19, 26-35, 42-49, 61-63; Steinberg, 15, 24, 364-89, Shell, 100).

Anthony Low once remarked that Crashaw has "fed our worst suspicions about the psychological linkages between sex and religion;" and "Blessed be the paps" has certainly confirmed the worst suspicions of many readers. Yet however controversial the scholarship of Rambuss and Steinberg, it does invite us to do something that Anthony Low thought was beyond the reach of most and that is to be "simultaneously and equally responsive to the pleasures of sexual gratification and of religious devotion” (The Reinvention of Love, 130). This is an important moment in Crashavian scholarship, one that is long overdue, and that the prescient Empson anticipated more than half a century ago when he observed: "Crashaw's poetry often has two interpretations, religious and sexual; two situations on which he draws for imagery and detail.” He wished to consider whether Crashaw was "generalising from two sorts of experience, or finding a narrow border of experience that both hold in common" (217-18). "Blessed be the paps” exhorts us to strive and find that narrow border. The words of Jesus himself articulate the textual challenge that the critical reader of Crashaw's epigram thus faces. "Try your hardest to enter by the narrow gate, because, I tell you, many will try to enter and will not succeed” (Luke 13: 24).

Let me now suppose that the psalm verse "taste and see that the Lord is good" opens this narrow gate and shows a way into the final line of the poem - "The Mother then must suck the Son" - with its brinkmanship balance of the sensual, the spiritual, and the prurient. In his superb study of the liminal or threshold state of mind that Crashaw's lyrics on Christ's wounds induce, Eugene Cunnar observes how ritual participants not only become oblivious to conventional differences and psychosocial boundaries but experience heightened physical awareness of the senses in which, as Victor Turner comments, they may "hear music and prayers, see visual symbols, taste consecrated foods, smell incense, and touch sacred persons and objects" ("Opening the Religious Lyric,” 241). This may condition the worshipper to see Christ's Passion, to taste his holy blood, and to touch his wounds; but it can also open the gates of the imagination and allow the fluids of abjection and polymorphous and perverse sexuality - semen, vaginal or menstrual discharge, excrement, tears, saliva, plasma and pus -- to flood through alongside the sacred blood and water issuing from Christ's side. 
Indeed, as Kristeva has pointed out, medieval mystics often imitated Christ by undergoing full bodily immersion in the baptismal waters of abjection $(5,127)$. St. Catherine of Siena who sealed her mystical marriage to Christ by wearing the ring of his circumcised and blood-stained foreskin, abjected herself even further by drinking the pus from the infected breast of a sick woman. This was done in extreme imitation of Christ's physical contact with the unclean during his gospel ministry. However St. Catherine's readiness to suck pestilence from the pap of a sick woman has close parallels with Crashaw's epigram with its suggestion that even as an infant at the breast, Christ hungered to become sin-eater on the Cross (Steinberg, 284, 290).. In recompense Christ comes to Catherine in a mystical vision on his five wounds, "tenderly placed his right hand on her neck, and drew her toward the wound in his side. 'Drink daughter, from my side,' he said, 'and by that draught your soul shall become enraptured with such delight that your very body, which for my sake you have denied, shall be inundated with its overflowing goodness"” (Cunnar, “Opening the Religious Lyric,” 248). Is this jouissance or psychopathology, an overflowing of the sacred or the perverse ${ }^{28}$

Francis Ford Coppola's 1992 film of Bram Stoker's Dracula draws attention to the fine line between the perverse and sacred, the sexual and the religious. ${ }^{29}$ In a scene which is uncannily both a transgressive parody and an ecstatic reenactment of St. Catherine's mystical marriage to Christ, Mina consummates her erotic union with Count Dracula by becoming a kind of saintly succubus and drinking the blood that pours from a phallic, mammary and vaginal wound he opens up in his side. Dracula's final redemption and apotheosis result from another mystical gesture of abjection when Mina demonstrates not only awe-inspiring but flesh-creeping devotion by kneeling and kissing his putrefying face. The film concludes by visualizing the shocking and offensive truth of the gospels: that compassion and love should overcome natural human revulsion or aversion. As Mina's last rites of abjection save Count Dracula, so Christ grants absolution to the woman who bathes his feet in abject kisses and tears. "Her sins, which are many, are forgiven; for she has shown great love” (Luke 7: 47-49). Is Christ only speaking here of the "great love" she has shown to him? Or is he also alluding to the many other men who may have come before him and whom she may also have touched, stroked, kissed, and sucked? ${ }^{30}$ If great love is born from "the brimming flesh of sin” (Kristeva, 126), then Richard Rambuss is right to argue that "sexual appetite and spiritual longing in their most intensified registers [are] homologous forms of desire" (98). Whatever sins of the flesh we can imagine in the "suck" 
that closes Crashaw's epigram, they are included in Christ's final act of forgiveness on the Cross where “sin [is] turned upside down into love.”31

Abjection produces the extreme behavior of St. Catherine of Siena and the extreme reactions of critical readers to Crashaw's devotional poetry. Abjection reduces us all to the lowest common denominator, born crying, as Augustine graphically envisaged, between faeces and urine, caught up in an endless cycle of purification to separate ourselves from the defilement of the body's overflowing emissions - piss, shit, semen, blood, milk, mucus, saliva, and tears. However the medieval mystic Julian of Norwich, who envisioned Christ in Crashaw's devotional terms as a lactating Mother nursing the faithful at his lanced side, also underlined the fact that God "comes down to us to the lowest part of our need; for he has no contempt of what he has made” (Pelphrey, 173). God is present in the uncontrollable mystery inter faeces et urinam ${ }^{32}$ and in the bodily sites which expel the abject waste of the body. God had no contempt for abjection. The message of Crashaw's epigram is this and more - Christ has redeemed the abject 'other.'

Crashaw has been deemed a minor poet (Williams, xxii), but it would be more illuminating to think of him as a poet of minorities. He speaks with the still, small voice of the conscience; and it makes him sensitive to the plight of all those who have been treated like dirt. Perhaps this is one of the reasons why women, Catholic and gay critics, acutely aware of what it means to be outsiders in the WASP literary establishment, have seen their own yearnings mirrored in his poetry and have produced some of his most passionate and thought-provoking critiques. ${ }^{33}$ The dark and violent spectacle of abjection framed Crashaw's life. As a boy, the bloody horror of religious torture, dismemberment and disemboweling was still fresh (Sabine, Feminine Engendered Faith, 216-18, 274). As a man at Peterhouse, there was the "Brooding Horror" ("Psalme 23," 1. 39, Williams, 6) of impending civil war. After the first major battle at Edgehill in October 1642, shortly before his own flight from Cambridge in early 1643 (Williams, xvii), there was the abjection of combat when, as Diane Purkiss observes, both sides were assailed by mutilation, carnage, “chaos, dissolution of boundaries, filth, loss of sight, loss of control, and loss of self” (22223, 234). Indeed as if haunted by this theater of war, his poetry is strewn with body parts and shows humans up close at their most vulnerable, bleeding, weeping, and dying.

Crashaw lived through Donne's worst fears in “The First Anniversarie”: “'Tis all in pieces, all cohaerence gone” (1. 213, Shawcross ed., 278). He fetishizes these pieces, magnifies 
parts of the body into exhibitionist objects of the eroto-religious gaze, and brings the 'dead' matter of abject body sites back to what many critics have regarded as unwholesome life. Often his devotional poems seem so absorbed in these body parts and their emissions that they lose sight - or seem to have little interest - in the picture as a whole. How then can readers find coherence in his poetry? The textual inspiration for "Blessed be the paps" suggests it is by attending to scripture. "Blessed are they who hear the word of God and keep it” (Luke 11:28). The word which makes overall sense of his poetry can be heard in Paul's first letter to the Corinthians on the parts of the body 12:12-27.

Paul underlines the fact that the body has many parts and that each part has a distinct purpose which is essential to the good of the whole. "God has put all the separate parts into the body as he chose. If they were all the same part, how could it be a body? As it is, the parts are many but the body is one. The eye cannot say to the hand, 'I have no need of you,' and nor can the head say to the feet, 'I have no need of you'” (18-21). Crashaw's poems focus on the part which reflects the need of the moment - eyes, hands, hair, feet, teat, bosom, lap, womb, mouth, cheeks, “MOTHER'S armes,” “FATHER'S knee (“A Hymn to Sainte Teresa,” l. 62, Williams, 55), heart. Rubens makes a similar point in two versions of the Descent from the Cross completed in 1617. In one painting in the Antwerp Museum, Mary Magdalene supports Christ's foot on her shoulder as his lifeless but uncannily muscular and powerful body is lifted off the Cross. In the Descent in the Musee des BeauxArts at Lille, Mary Magdalene now kisses Christ's wounded hand while John appears to lick the blood still spilling from his lanced side. ${ }^{34}$ While the Magdalene's eye focuses on the foot in the Antwerp painting, the Lille version shows that it also has need of the hand. Mary Magdalene is a reminder that the reader of Christ's body will inevitably be partial-sighted.

Paul's letter to the Corinthians is also a reminder that while Christ shares our broken and wounded humanity by allowing his life to spill out on the Cross, his mystical body holds all of the parts together and makes them whole. "Now Christ's body is yourselves, each of you with a part to play in the whole” (27). Not only does Crashaw's poetry insist that each part of the body - and of the members who constitute the body of Christ - serve some indispensable function in the Redemptive plan, but each is acceptable in God's eyes. Moreover, as Paul emphasizes, "it is precisely the parts of the body that seem to be the weakest which are the indispensable ones. It is the parts of the body which we consider least 
dignified that we surround with the greatest dignity; and our less presentable parts are given greater presentability which our presentable parts do not need” (22-24).

In this essay, I have looked at the abject parts of the body that have the least dignity, that are a sign of our human weakness, most dramatically illustrated in the early moments of infancy and the final moments of death, and that, in the words of David Punter, reflect "our inability to hold ourselves together” (16). Crashaw’s “Blessed be the paps” suggests a whole range of bodily activities that are not dignified or presentable, and that underline not only human weakness and disintegration but debasement, from breastfeeding to sucking, oral sex and incest. Crashaw shows us what Julian of Norwich beheld, that God "comes down to us to the lowest part of our need; for he has no contempt of what he has made” (Pelphrey, 173). He invites us to bring our "lowest" bodily functions and needs to the foot of the Cross so that our partial and partisan vision, both as human beings and critical readers, can be lifted up and completed in God's sight. "Blessed be the paps" proclaims that it is not homage to the 'Mother," but faith in the body of Christ she birthed, nursed, and laid to rest that makes us whole.

\footnotetext{
${ }^{1}$ Dianne Chisholm suggests how Kristeva's theory of abjection develops out of Freudian thought in her discussion of the uncanny in Feminism and Psychoanalysis: A Critical Dictionary, ed. Elizabeth Wright (Oxford: Blackwell, 1992), 439. See Freud's own understanding of the concept in his essay "The 'Uncanny'," Art and Literature, Vol. 14, Penguin Freud, ed. Albert Dickson (London: Penguin, 1990), especially 354-55, 363-65, 368-72. In his essay on "The Theme of the Three Caskets" in the same volume, Freud suggests that the mother can provoke uncanny fears as creator and destroyer (244-47).

${ }^{2}$ I shall be quoting Crashaw's poetry parenthetically from George Walton Williams's edition of The Complete Poetry of Richard Crashaw (New York: New York University Press, 1972). "The Flaming Heart" is on 61-65.

${ }^{3}$ See Diane Purkiss' powerful account of the horrors of abjection that assailed both Parliamentarian and Royalist soldiers on the civil war battlefield in "Dismembering and Remembering: The English Civil War and Male Identity,” The English Civil War in the Literary Imagination [electronic resource], ed. Claude J. Summers \& Ted-Larry Pebworth (Columbia: University of Missouri Press, 1999), 22327.

${ }^{4}$ Elizabeth Drury died in December 1610. R.C. Bald, John Donne: A Life (Oxford: Clarendon, 1970), 241-44, believes that Donne wrote "The First Anniversarie" in late summer or early autumn 1611. L.C. Martin, editor of The Poems English, Latin and Greek of Richard Crashaw (Oxford: Clarendon, 1957), xvii, thinks that Crashaw was born either at the end of 1612 or beginning of 1613. Successive editions of the Anniversaries were published after Crashaw's birth and a comprehensive collection of Donne's poetry was published when Crashaw was a promising undergraduate and poet at Pembroke. Donne's "First Anniversarie" is cited from John T. Shawcross' edition of The Complete Poetry of John Donne (Garden City, N.Y.: Doubleday-Anchor, 1967), 277. Leo Steinberg traces the notion that original sin was transmitted genitally and genetically to Augustine's treatises On Marriage and Concupiscence and On the Literal Meaning of Genesis. See The Sexuality of Christ in Renaissance
} 
Art and in Modern Oblivion, $2^{\text {nd }}$ ed. rev. and expanded (Chicago \& London: The University of Chicago Press, 1996), 18-19, 238.

${ }^{5}$ Paul A. Parrish pursues this point in "Richard Crashaw, Mary Collet, and the 'Arminian Nunnery' of Little Gidding," Representing Women in Renaissance England, ed. Claude J. Summers \& Ted-Larry Pebworth (Columbia \& London: University of Missouri Press, 1997), 188, 195, and more generally in "The Feminizing of Power: Crashaw's Life and Art," "The Muses Common-Weale": Poetry and Politics in the Seventeenth Century, ed. Claude J. Summers \& Ted-Larry Pebworth (Columbia: University of Missouri Press, !988), 148-62.

${ }^{6}$ David Reid remarks that Crashaw's “enthusiasm for bosoms, breasts, milk and nests is notorious” in The Metaphysical Poets (Harlow, England: Longman, 2000), 162.

${ }^{7}$ Steinberg discusses the hierarchical order of the body in The Sexuality of Christ, 149-50, and notes on 151 that the euphemism feet expressed the view that the genital organs were the lowest part of the body.

${ }^{8}$ In her study of Mary Magdalen: Myth and Metaphor (London: Harper Collins, 1993), 247-48, Susan Haskins notes that from the fourteenth century, Mary Magdalen's hair was depicted as either red or golden. Crashaw envisions her tresses as red-gold in this epigram.

${ }_{9}^{9}$ What Anthony Low says of "On the wounds of our crucified Lord" is also true of "On our crucified Lord Naked, and bloody." "We begin with close-ups. ... The focus is closely on the wounds from the beginning; there is no attempt to see the Crucifixion as a whole." See Love's Architecture: Devotional Modes in Seventeenth-Century English Poetry (New York: New York University Press, 1978), 124-25. 10 "Poet and Saint" was the apt description of the seventeenth century biographer David Lloyd recalling Crashaw's ecstatic performance in the pulpit at Little St. Mary's, Peterhouse. See the Martin ed., 416 and the Williams ed., xvi.

${ }^{11}$ See, for example, Low, Love's Architecture, 116, 157; Reid, 142; Alison Shell, Catholicism, Controversy and the English Literary Imagination 1558-1660 (Cambridge University Press, 1999), 102-03; David Punter, Writing the Passions (Harlow, England: Longman, 2001), 54-55; Eugene R. Cunnar, "Opening the Religious Lyric: Crashaw's Ritual, Liminal, and Visual Wounds," New Perspectives on the Seventeenth-Century English Religious Lyric, ed. John R. Roberts (Columbia \& London: University of Missouri Press, 1994), 237-38; Robert V. Young, Richard Crashaw and the Spanish Golden Age (New Haven: Yale University Press, 1982), 24-26; and Patrick Grant, Images and Ideas in the Literature of the English Renaissance (Amherst: University of Massachusetts Press, 1979), 89-93. See my summary in "Crashaw and the Feminine Animus: Patterns of Self-Sacrifice in Two of his Devotional Poems," JDJ 4 (1985): 69-70, 92 and Feminine Engendered Faith: The Poetry of John Donne and Richard Crashaw (London: Macmillan, 1992), 112-113, 154-55, 174, 185-90; that of Lorraine M. Roberts \& John R. Roberts, "Crashavian Criticism: A Brief Interpretative History," New Perspectives on the Life and Art of Richard Crashaw, ed. John R. Roberts (Columbia \& London: University of Missouri Press, 1990), 1-29; and Richard Rambuss' more recent comments on the queerness of the metaphysical poets and Crashaw particularly in Closet Devotions (Durham \& London: Duke University Press, 1998), 17-19, 34, 145-46.

12 Jewish law perpetuated the myth of Samaritan women's uncleanliness by deeming them “menstruants from their cradle.” See Haskins’ note 57, 406.

${ }^{13}$ See my discussion of the divine epigrams and this period in Crashaw's life in chapter four of Feminine Engendered Faith, 111-145.

${ }^{14}$ See Robert V. Young's discussion in "Crashaw and Biblical Poetics," New Perspectives on the Life and Art of Richard Crashaw, 30.

${ }^{15}$ I am thinking here of the shining raiment in which the two angels who announce Christ's Resurrection are clothed in Luke 24: 4-6.

${ }^{16}$ I have already discussed these Latin epigrams as they prefigured Crashaw's mature formulation of feminine engendered faith in major English poems on the Virgin Mary, St. Teresa of Avila, Mary Magdalene, and other holy women. See Feminine Engendered Faith, 115-15, 122, 140-45, where I suggested that his memorable epigram, "A woman, and of such strong faith? Now I believe that faith is/more than grammatically of the feminine gender" (Williams, 334) paradoxically demonstrates the 
Christian strength that comes from gender weakness. See Paul Parrish on "The Feminizing of Power," 156.

${ }^{17}$ The early biographer Lloyd underlines Crashaw's remarkable linguistic skill in seven ancient and modern languages. See the Martin ed., 416.

${ }^{18}$ Rambuss speculates provocatively in $\mathrm{n} .11,141$ that "perhaps even more than is the case with Donne, reading Crashaw has been critically constituted as something of a dirty pleasure.” This essay was inspired, in part, by the view that too often critics have wiped the dirt clean from his poetry or too quickly sought relief in anagogical readings. William Empson was one of the first modern critics to call a spade a spade in suggesting how Crashaw uses horror to "excite adoration" in Seven Types of Ambiguity (New York: New Directions, 1966), 221. Elizabeth Clarke remarks that "many critics are uncomfortable with what Healy calls his (Crashaw's) 'indecorous' rhetoric. Richard Rambuss has highlighted the explicit eroticism of his poetry, ... disputing the tendency to allegorical interpretation that would de-sexualize the imagery." See her fair assessment of the critical pros and cons in "Religious Verse," A Companion to English Renaissance Literature and Culture, ed. Michael Hattaway (Oxford: Blackwell, 2000), 416-17.

${ }^{19}$ In this instance, I have used the wording in the King James version instead of The New Jerusalem Bible because it is adopted as the title of Crashaw's English epigram.

${ }^{20}$ See the discussion of the phallic mother in Feminism and Psychoanalysis, 55, 314-15.

${ }^{21}$ Kristeva focuses on the woman of Canaan's abjection before Christ and ignores the faith and love that motivate it, turn abasement into prayer -- a prayer for her daughter's recovery that is immediately answered.

${ }^{22}$ Rambuss reads this epigram as "less an emblem of religious androgyny than one of a more radical gender undecidability." Yet he goes on to argue that critics too quickly efface the maleness of Jesus' body and move on to the mystical affirmation of Jesus as phallic mother in the final line of this controversial poem. As a queer reader of Crashaw's devotional poetry, Rambuss is more interested in "the possibilities a male Christ affords for a homoeroticized devotional expression" (37-39). My point is that the epigram is pressuring readers to imagine themselves differently before they envisage 'other' likenesses of Christ. Rambuss' reading is nonetheless important because it considers "perverted sexual implications," especially in n. 34, 145-46, which have hitherto been dismissed as mistaken or regarded -- like Crashaw's poetry itself -- as the product of an over-heated imagination. See Cunnar, "Opening the Religious Lyric," 259-60 and Steinberg, 377-78 who argues that the nourishing breast of Christ in this epigram does not simply resemble the paps in the title but the womb that is blessed.

${ }^{23}$ On the allusion to the Last Supper in these lines, Robert Young's brilliant comment is that they show "the scandalous origin of the Eucharist and the startling nature of taking communion" (Richard Crashaw and the Spanish Golden Age, 26).

${ }^{24}$ Rambuss rightly observed in his note 34 on 145 that "though his interpretations continue to vex most Crashavians, Empson remains the poet's best critic, appropriately matching in such readings Crashaw's extravagance with his own."

${ }^{25}$ Thomas Healy argues in "Crashaw and the Sense of History," New Perspectives on the Life and Art of Richard Crashaw, 52 that "the exaggerated quality of Christ's teat [makes it] difficult to compose a visual emblem of the scene, as suggested by the epigram." Cunnar, "Opening the Religious Lyric," 238, agrees that "it is difficult to visualize what are commonly thought to be perverse or grotesque images, even on a psychological level." Steinberg echoes these views in maintaining on 377-78 that Christ's teat is impossible to visualize. Yet Crashaw's epigram is a direct challenge to the unbelief that derives from the steely mind and stony heart. To quote John 12: 40: "He has blinded their eyes, / he has hardened their heart, to prevent them from using their eyes to see, using their heart to understand, / changing their ways and being healed by me.”

${ }^{26}$ Paul Parrish’s general observation on Crashaw's devotional poetry about and for women is welltaken here. "There is not only a pervasive interest in the maternal and in maternalizing circumstances and events, but that such instances often coincide with and reinforce erotic and sensual moments, the maternal both enhancing the eroticism and, paradoxically, keeping it in check." See "Writing About 
Mother: Richard Crashaw and the Maternal Body,” Performance for a Lifetime: Essays on Women, Religion and the Renaissance in Honor of Dorothy H. Brown, ed. Barbara Ewell \& Mary McCoy (New Orleans: Loyola University Press, 1997), 229.

${ }^{27}$ See Diana Trevino Benet's judicious weighing up of Crashaw's complicated attitude to the visual and verbal in "Crashaw, Teresa, and the Word," New Perspectives on the Life and Art of Richard Crashaw, 140-56.

${ }^{28}$ Though this vision may seem extreme, Catherine of Siena was one of the writers Crashaw's antiPapist father included in his religious library. See Feminine Engendered Faith, 173, n. 10, 272.

${ }^{29}$ Rambuss underlines the "profoundly unsettling" and "devotionally provocative" nature of "Blessed be the paps" by a daring intertextual comparison with the 1973 horror film The Exorcist in n. 34, 14546.

${ }^{30}$ As Haskins notes on 19, scriptural commentators have engaged in frequent speculation as to whether Christ's compassionate words allude to the woman's sexual history.

${ }^{31}$ Kristeva is commenting on this gospel passage in Luke (122-23).

${ }^{32}$ Augustine is quoted in Rambuss, 21.

${ }^{33}$ In a long overdue study of Catholicism, Controversy and the English Literary Imagination, Alison Shell remarks that "there would be a good case for including the Elizabethan or Stuart Catholic alongside women, racial minorities, Jews, homosexuals and the common sort in lists of the historically downtrodden" (17-18).

${ }^{32}$ Cunnar discusses both paintings, the first in "Crashaw's 'Sancta Maria Dolorum': Controversy and Coherence," New Perspectives on the Life and Art of Richard Crashaw, 119-121; and the second in "Opening the Religious Lyric," 251-53. The two paintings are reproduced in his essays.

References

Benet, Diana Trevino. "Crashaw, Teresa, and the Word." New Perspectives on the Life and Art of Richard Crashaw, 140-56. Ed. John R. Roberts. Columbia \& London: University of Missouri Press, 1990.

Carroll, Lewis. The Annotated Alice: Alice's Adventures in Wonderland \& Through the Looking Glass. rev. ed. Ed. Martin Gardner. London: Penguin, 1970.

Chisholm, Dianne. “The Uncanny.” Feminism and Psychoanalysis: A Critical Dictionary. 436-40. Ed. Elizabeth Wright. Oxford: Basil Blackwell, 1992.

Chodorow, Nancy. The Reproduction of Mothering: Psychoanalysis and the Sociology of Gender. Berkeley: University of California Press, 1979.

Clarke, Elizabeth. "Religious Verse.” A Companion to English Renaissance Literature and Culture. 404-18. Ed. Michael Hattaway. Oxford: Blackwell, 2000.

Crashaw, Richard. The Complete Poetry Ed. with introd. \& notes, George Walton Williams. New York: New York University Press, 1972.

Press, 1957. The Poems English, Latin and Greek. $2^{\text {nd }}$ ed. Ed. L.C. Martin. Oxford: Clarendon

Cunnar, Eugene R.. “Crashaw's 'Sancta Maria Dolorum': Controversy and Coherence.” New Perspectives on the Life and Art of Richard Crashaw. 99-126. Ed. John R. Roberts. Columbia \& London: University of Missouri Press, 1990.

"Opening the Religious Lyric: Crashaw’s Ritual, Liminal, and Visual Wounds." New Perspectives on the Seventeenth-Century English Religious Lyric. 237-67. 
Ed. John R. Roberts. Columbia \& London: University of Missouri Press, 1994.

Donne, John. The Complete Poetry. Ed. with introd, notes \& variants, John T. Shawcross. Garden City, New York: Doubleday-Anchor, 1967.

Empson, William. Seven Types of Ambiguity. New York: New Directions, 1966.

Feminism and Psychoanalysis: A Critical Dictionary. Ed. Elizabeth Wright. Oxford: Basil Blackwell, 1992.

Freud, Sigmund. “The Theme of the Three Caskets (1913)” and “The 'Uncanny' (1919).” Art and Literature. 235-47, 339-76. Vol. 14, Penguin Freud Library. Ed. Albert Dickson. Trans. James Strachey. London: Penguin, 1990.

Grant, Patrick. Images and Ideas in the Literature of the English Renaissance. Amherst: University of Massachusetts Presss, 1974.

Haskins, Susan. Mary Magdalen: Myth and Metaphor. London: Harper Collins, 1993.

Healy, Thomas F.. "Crashaw and the Sense of History." New Perspectives on the Life and Art of Richard Crashaw. 49-65. Ed. John R. Roberts. Columbia \& London: University of Missouri Press, 1990.

Klein, Melanie. Love, Guilt and Reparation. reprint. London: Virago Press, 1994.

Kristeva, Julia. Powers of Horror: An Essay on Abjection. Trans. Leon S. Roudiez. New York: Columbia University Press, 1982.

Low, Anthony. Love's Architecture: Devotional Modes in Seventeenth-Century English Poetry. New York: New York University Press, 1978.

. The Reinvention of Love: Poetry, Politics and Culture from Sidney to Milton.

Cambridge University Press, 1993.

New Perspectives on the Life and Art of Richard Crashaw. Ed. John R. Roberts. Columbia \& London: University of Missouri Press, 1990.

Parrish, Paul A.. "Richard Crashaw, Mary Collet, and the 'Arminian Nunnery' of Little Gidding." Representing Women in Renaissance England. 187-200. Ed. Claude J. Summers \& Ted-Larry Pebworth. Columbia \& London: University of Missouri Press, 1997.

"The Feminizing of Power: Crashaw's Life and Art." "The Muses Common-Weale": Poetry and Politics in the Seventeenth Century. 148-62. Ed. Claude J. Summers \& Ted-Larry Pebworth. Columbia: University of Missouri Press, 1988.

"Writing about Mother: Richard Crashaw and the Maternal Body." Performance for a Lifetime: Essays on Women, Religion and the Renaissance in Honor of Dorothy $H$. Brown. 223-38. Ed. Barbara Ewell \& Mary McCoy. New Orleans: Loyola University Press, 1997.

Pelphrey, Brant. Christ Our Mother: Julian of Norwich. London: Darton, Longman \& Todd, 1989.

Punter, David. Writing the Passions. Harlow, England: Longman, 2001.

Purkiss, Diane. "Dismembering and Remembering: The English Civil War and Male Identity." The English Civil Wars in the Literary Imagination. 220-41. [electronic resource] Ed. Claude J. Summers\& Ted-Larry Pebworth. Columbia: University of Missouri Press, 1999.

Rambuss, Richard. Closet Devotions. Durham \& London: Duke University Press, 1998.

Reid, David. The Metaphysical Poets. Harlow, England: Longman, 2000.

Roberts, Lorraine M. \& John R.. "Crashavian Criticism: A Brief Interpretative History." New Perspectives on the Life and Art of Richard Crashaw. 1-29. Ed. John R. Roberts. Columbia \& London: University of Missouri Press, 1990.

Sabine, Maureen. "Crashaw and the Feminine Animus: Patterns of Self-Sacrifice in Two of his Devotional Poems.” JDJ 4 (1985): 69-94.

. Feminine Engendered Faith: The Poetry of John Donne and Richard Crashaw.

London: Macmillan, 1992.

Shell, Alison. Catholicism, Controversy and the English Literary Imagination 1558-1660. Cambridge University Press, 1999. 
Steinberg, Leo. The Sexuality of Christ in Renaissance Art and in Modern Oblivion. $2^{\text {nd }}$ ed. rev. \& expanded. Chicago \& London: The University of Chicago Press, 1996.

Stokes, Adrian. Reflections on the Nude. London: Tavistock, 1967.

Young, Robert V.. "Crashaw and Biblical Poetics," New Perspectives on the Life and Art of Richard Crashaw. 30-48. Ed. John R. Roberts. Columbia \& London: University of Missouri Press, 1990. Richard Crashaw and the Spanish Golden Age. New Haven: Yale University - 19 -Press, 1982.

\section{Maureen Sabine,}

Department of History,

University of Hong Kong, Pokfulam 